\title{
Osteobiography: A Platform for Bioarchaeological Research
}

\author{
Lauren Hosek ${ }^{\mathrm{a} *}$ and John Robb ${ }^{\mathrm{b}}$ \\ ${ }^{a}$ Department of Anthropology, Syracuse University, Syracuse, NY 13244, USA \\ ${ }^{b}$ Department of Archaeology, University of Cambridge, Downing Street, Cambridge CB2 3DZ, UK \\ *Correspondence to: Lauren Hosek, Syracuse University, 209 Maxwell Hall, Syracuse, NY 13244, USA \\ e-mail:1rhosek@syr.edu
}

ABSTRACT Osteobiography provides a rich basis for understanding the past, but its conceptual framework has not been outlined systematically. It stands in conceptual opposition to a traditional statistical approach to bioarchaeology modeled upon clinical studies in biomedicine, but is interdependent with it. As such, its position mirrors those of clinical case histories as opposed to statistical studies, participant-observation ethnography as opposed to quantitative sociology, and microhistory and biography as opposed to quantitative history. Such disciplinary comparisons provide a framework for exploring the strengths and weaknesses of osteobiography. It is not merely a tool for engagingly illustrating the "typical" life history as established statistically. Rather, it allows us to understand issues that population studies cannot explore. These include both analytical directions (exploring the complexity of deeply layered data, understanding the role of contingency in human lives, integrating osteological and cultural evidence) and philosophical directions (the interaction of material and conceptual factors in the creation of human bodies, embodiment, the experience of time).

Keywords: life history; biography; theoretical approaches

La osteobiografía ofrece una base rica para comprender el pasado, pero su marco conceptual no se ha delineado de manera sistemática. Se encuentra en oposición conceptual a un enfoque estadístico tradicional de la bioarqueología formado sobre estudios clínicos en biomedicina, pero es interdependiente de él. Su posición, como tal, refleja aquellos casos de historias clínicas opuestos a los estudios estadísticos, la etnografía de observación participativa opuesta a la sociología cuantitativa, y la microhistoria y la biografía opuestas a la historia cuantitativa. Semejantes comparaciones disciplinarias ofrecen un marco para explorar las fortalezas y debilidades de la osteobiografía. No es simplemente una herramienta para ilustrar de manera atractiva la historia "típica" de la vida según lo establecido estadísticamente. Más bien, nos permite entender las cuestiones que los estudios de población no pueden explorar. Estas incluyen direcciones analíticas (explorando la complejidad de datos en capas profundas, comprendiendo el papel de la contingencia en las vidas humanas, integrando la evidencia osteológica y cultural) y direcciones filosóficas (la interacción de factores materiales y conceptuales en la creación de cuerpos humanos, encarnación, la experiencia del tiempo).

la historia de la vida; la biographía; los enfoques teóricos

Copyright (C) 2019 University of Florida Press

Received 30 July 2018

Revised 4 January 2019

Accepted 5 January 2019 
"Osteobiography" is a concept that has become popular in recent years, but it remains poorly theorized and has not had systematic methodological exploration. As it is currently used, it remains much as Saul (1972) originally formulated it: osteobiography involves assembling all information available from the skeleton to create a life narrative for a single individual. This definition is certainly a stimulating starting point, but it does not do full justice to the concept's potential. Why has the idea not grown and matured in the generation since it was coined?

The answer may lie in the dominant biomedical paradigm in which bioarchaeology has grown, which is traceable to its twin roots in skeletal biology and socially oriented processual archaeology. Bioarchaeology has broadened greatly in the last decade, exploring new directions such as individual variation, the life course, identity, embodiment, and social theory (see Baker and Agarwal 2017). Examples include theorization of how social relations form the "biological" body (Sofaer 2006); discussion not only of how to diagnose pathological lesions and what their medical or epidemiological significance was, but also of what they meant for ancient people's life experiences (Baker and Bolhofner 2014; Fay 2006; Kieffer 2017; Marsteller et al. 2011; C. A. Roberts et al. 2016) and social relations such as the "bioarchaeology of care" (Hawkey 1998; Tilley 2015; Tilley and Oxenham 2011; Vlok et al. 2017); problematizing sex and gender as non-trivial theoretical problems in bioarchaeology (Geller 2016); problematizing age as a social dimension rather than simply a chronometric indicator (Sofaer 2006, 2011); and movements to integrate funerary taphonomy with the question of social agency after death (e.g., Cambridge Archaeological Journal special section 2014).

The field is broadening to encompass a new, more humanistic bioarchaeology. Yet there remains a methodological and conceptual core that focuses mostly upon establishing significant relationships among variables such as age, sex, disease, activity, and social status. This research is normally done through statistical analyses such as correlation. Within this traditional paradigm, the status of osteobiography is unclear. It may be considered a useful scholarly exploration of what statistical relations mean when viewed "on the ground" in an individual life. But it may also be dismissed as simply a tool for engaging the public in a popular book or museum exhibition through human interest stories; the most rigidly quantitative practitioners may see it as unscientific, as a sample size of one cannot "prove" a general point (but see articles in this issue).

Our core argument here is that osteobiography is not simply an engaging extension tacked on to, and perhaps overstretching, a traditional population-level, quantitative bioarchaeology. Instead, it forms an indispensable tool within a broader, emerging humanistic bioarchaeology, a tool that poses and responds to different kinds of research questions. These research questions are explored below. Moreover, we are at an especially propitious moment to revisit and redevelop the concept of osteobiography. An ensemble of new analytical methods, including isotopic studies of diet and geographical movement during life, aDNA studies of individuals' physical characteristics, and aDNA studies of pathogen exposure and the human microbiome, are adding new layers of depth to our ability to reconstruct humans' life experiences. With explicit theorization and methodology, we propose that osteobiography has greater potential as a research tool within socially contextualized bioarchaeology.

How do osteobiographical and quantitative approaches relate to one another? The answer is straightforward, perhaps obvious. Neither approach is adequate on its own. Osteobiography allows insight into the structure of individual lives in a way that populationlevel study cannot. Yet we can only make sense of an individual life by putting it into its social context. What is exceptional for one group falls squarely within normal variation for another. Conversely, relying exclusively upon biomedical-style populationlevel statistical studies has limitations, writing off potential information about individual variation as "noise." Such an approach flattens out the complexities and contingencies of individual lives (Stodder and Palkovich 2012; Mays et al. 2018). Moreover, population-level statistical studies structure how data are collected and reported. As an example, various landmark skeleton collections have been studied many times to elucidate statistical relations between specific variables, but in a way that makes it impossible to combine data from them into multi-layered databases. A focus on individual lives can help populationlevel studies by revealing reasons why data may vary. Osteobiography and population-level studies are thus interdependent and complementary, and a full exploration of a group and its lives may involve tacking back and forth between them.

The osteobiographies in this issue, as well as many of those reviewed below, show how a more theoretically informed osteobiographical approach can address at least three significant research directions:

1. Understanding how ancient people perceived, felt, and responded to bodily processes such as appearance, health and illness, violence, aging, and death merits exploration. Within a humanistic bioarchaeology, we can, and should, ask how ancient people experienced their lives. We can do so without being naive about either the philosophical issues 
involved in understanding human experience or the complexity of health and the body as cultural constructs.

2. We do not live within a bivariate world. Human lives are structured not only by deterministic, statistical relations between abstract factors but also by chance, historical contingency, and the interaction of complex networks of circumstances. Such interactions unfold in a way ordered over time to create important outcomes not simply predictable from generalizations about the variables involved (as in the concept of the "perfect storm"). These contingent outcomes are recognized within biomedicine by the complementary tradition of individual case studies alongside population-based statistical studies. Similarly, most of the social sciences provide methods for statistical studies of underlying regularities (e.g., economic history, quantitative sociology) and for tracing the developmental pathways of individual cases, whether typical or exceptional (e.g., microhistory, biography, ethnographic analysis). Understanding how general factors and historical contingencies interact to create specific human lives is an important topic in itself.

3. The shape of human lives may vary socially and undergo historical change. This concept has been suggested both by historians (e.g., in debates about the nature of childhood in ancient society) and by evolutionary biologists (e.g., in studies of life history). It is also important in modern society; one has only to consider how events such as teenage pregnancy act as switches routing people onto different life courses. Hypotheses about the multigenerational consequences of maternal health (Barker et al. 2002; Gowland 2015) provide a current archaeological example. This dimension is potentially very important but relatively unexplored; it requires developing new methods for analyzing osteobiographies not only as individual life histories but also as comparative points of reference that reveal the shape of human lives.

This special issue originated as a conference symposium revisiting osteobiography at the 2017 Society for American Archaeology meetings in Vancouver, British Columbia, to which many of the participants have contributed. Each article builds on the concept of osteobiography and offers novel methodological approaches, theoretical explorations, or the possibility of new frontiers. Contributions characterize emerging theoretical directions in osteobiography. These include the intersectionality of identity, the role of narrative in the presentation of data, and the ethics of osteobiography. This introduction provides a systematic overview to the concept of osteobiography and serves as a platform for developing this research agenda further. We outline some key underlying concepts and methods as well as future directions that we hope will push the boundaries of osteobiography and demonstrate its potential as an analytic tool.

\section{Biographical Approaches within Bioarchaeology}

The term "osteobiography" was conceived early in the history of bioarchaeology as part of attempts to bring skeletal data out of the ghetto of appendixes of archaeological reports (Baadsgaard et al. 2012; Buikstra 2006; Buikstra et al. 2011). The concept was initially developed by Frank and Julie Saul as a methodological framework for reconstructing the lives of Maya individuals, developing life histories from human remains (Saul and Saul 1989). Frank Saul (1972:8) first coined the term in the early 1970s, explaining that osteobiography "has been used to indicate in a single word that this study is concerned with all of the foregoing aspects of skeletal analysis." Saul applied this approach to skeletal remains from the Mayan site Altar de Sacrificios, intending for these skeletal life histories to encompass contextualized analyses of age, sex, pathology, trauma, and activity. Saul and Saul (1989) developed osteobiography further by using individual life histories to make projections about the wider skeletal sample. They acknowledged the origins of osteobiography in forensic anthropology and the work of archaeologists including E. A. Hooton and biological anthropologists including W. M. Krogman and J. L. Angel (Buikstra 2006). This original conception of osteobiography has been critiqued for lacking serious consideration of the archaeological context of skeletal remains and for approaching population-based questions with data specific to individuals (Buikstra and Scott 2009; Geller 2014), but it has provided a foundation for bioarchaeological approaches to individual lives.

Within theoretical bioarchaeology, two key lines of thought have influenced later manifestations of osteobiography. The first is an acknowledgment of the biosocial nature of the body as a material object influenced by both biological and cultural forces (Sofaer 2006). Joanna Sofaer's initial call to reevaluate the archaeological body has since been advanced to understand how traces of the life course are embodied in the skeleton itself (e.g., Buikstra et al. 2011). Bioarchaeologies of childhood (Beauchesne and Agarwal 2018; Lewis 2007; Thompson et al. 2014) and old age (Appleby 2011; Cave and Oxenham 2016) have grappled with the material and social outcomes of bodily plasticity in these age spectrums. In her own work, Sofaer 
attempts to reconcile biological age estimations with culturally contextual understandings of age as social process (Sofaer 2011; Sofaer Derevenski 2000) as well as categories of biological sex with the diverse lived experiences of gender (Sofaer 2006; Sofaer and Sørensen 2013). The second theoretical focus within bioarchaeology has been a concern with the life course, typified by Sabrina Agarwal's $(2012,2016)$ exploration of agerelated biological development sequences occurring within social contexts. An emphasis on social bioarchaeology has emerged from these interests in identity and the life course, prioritizing human social contexts in the study of skeletal remains (Agarwal and Glencross 2011; Gowland and Knusel 2006; Knudson and Stojanowski 2009).

As part of these trends in theoretical bioarchaeology, osteobiography gained new attention through Robb's (2002:160) expansion of the concept as "the study through human skeletons of the biography as a cultural narrative" with the intent to discern "cultural understandings of life events and to encompass the history of human remains after death." In this conception, the life history of an individual is structured by cultural categories including age, gender, and socioeconomic statuses that define various stages of life. An individual life is entangled within social and cosmological temporalities that inform the different paths a life may take. Robb's example of a Neolithic female's life history from the Italian Catignano site demonstrates how a contextualized skeletal biography can shed light on the embodied experiences of biological processes such as illness, injury, and cultural modification of the body. Importantly, Robb and others (Geller 2012) have added death histories to the osteobiographical project, acknowledging that people often continue to be social actors in some form after biological death. Such postmortem agency might be accessed through careful contextualization of skeletal remains within archaeological contexts.

Alongside the revitalization of osteobiography came a renewed interest in the life experiences of individuals as a counter to epidemiological approaches to past populations. A number of works, including many of those in Stodder and Palkovich's (2012) The Bioarchaeology of Individuals, began to address agency, structure, and the relationships between individuals and populations through a biography of skeletal remains. Osteobiography was invoked in some of these projects as a humanistic means of bringing individual people back to life, both for ourselves and as a way of helping non-archaeologists imagine the past (Boutin 2011, 2012, 2016; Stojanowski and Duncan 2015). These osteobiographies tended to illustrate ordinary lives, acting as case studies introducing an individual to exemplify a site or population. A contrasting theme emerges in other works: the use of osteobiography, or at least the concept of individual life history, to describe distinctive individuals or mortuary contexts.

A few notable examples are "Skrydstrup Woman" from Denmark (Frei et al. 2017), the Bronze Age "Egtved Girl" (Frei et al. 2015) and "Gristhorpe Man" (Melton et al. 2013), the Iron Age "Princess of Vix" (Knüsel 2002), the Mesolithic shaman burial of Bad Dürrenberg (Porr and Alt 2006), and a seventeenthcentury Finnish clergyman (Väre 2017). Other osteobiographies involve multiple individuals, as in the case of the sailors of the Mary Rose (Stirland 2000), a Corded Ware burial group (Meyer et al. 2009), three medieval individuals from Trondheim (Hamre et al. 2017), and four individuals from Stonehenge (Mays et al. 2018). New World examples include Buikstra's Hopewell mound burial (1976), elite burial contexts in Oaxaca (Mayes and Barber 2008) and Palenque (Couoh 2015), a Paleoindian individual from Brazil (Lessa and Guidon 2002), and the Moatfield Ossuary in Ontario (Williamson and Pfeiffer 2003). Interestingly, there is at least one osteobiography of a nonhuman animal: Tourigny et al. (2016) describe the life history of a nineteenth-century dog from Canada.

Overall, these osteobiographies show three common features: (a) a principal, though not exclusive, focus on European cases; (b) accelerating tempo in rate of publication, in part related to increasing public engagement and academic publishing pressures, but also to new methods that allow us to reconstruct more complex and interesting life stories; (c) common methods, including osteology, palaeopathology, isotopic analysis, and detailed articulation with archaeological contexts. We have noticed divergences in approach in different areas; for instance, our impression is that osteobiographies of prehistoric people tend to focus more upon lives as expressions of general social conditions, while a strong tradition in text-aided osteobiographies has been identification of specific individuals and exploration of social differences within society. There are also common presentational methods, especially facial reconstruction and creation of a name for these unknown individuals. Museum exhibitions, in particular, use the latter methods of representation, often based on extensive scientific work but also uniformly involving faces and names. Notable examples include Vasa Museum (Stockholm), the Mary Rose Museum (Portsmouth), the Yorkshire Museum (York), and the African Burial Ground National Monument (New York).

Famous bodies are particularly prone to this kind of reconstructive treatment, in part because of their ability to capture the public's imagination and further inform on well-known histories (Stojanowski and Duncan 2015). These "celebrity bodies" include King 
Tutankhamun (Rühli and Ikram 2014), "Ötzi," the Neolithic Alpine Iceman (Robb 2009), the recently recovered body of Richard III (Appleby et al. 2015; Toon and Stone 2016), the prehistoric Paleoamerican known as Kennewick Man or the Ancient One (Owsley and Jantz 2014), and bog mummies such as Lindow Man (Stead et al. 1986). Even as powerful tools for public engagement, these osteobiographies and the bells and whistles of facial reconstruction and documentary reenactments that often accompany them cannot be viewed uncritically. Reconstruction of these archaeological bodies in text and media, for both academic and popular audiences, results in an ancient person with a "biography and bodily constitution mirroring those familiar to modern Western Europeans" (Robb 2009:123). While bringing the past "to life," what narratives are we reinforcing, and what might we lose in (re)constructing these faces and names? And what can we learn that is not already known from their historical biographies? Appleby (this issue) provides an exciting example of how Richard III's osteobiography gives insights not only into Richard's life but into medieval habitus.

Similar questions arise in the related tradition of biohistory (Komar and Buikstra 2008; Stojanowski and Duncan 2017). The intellectual agenda of biohistory is closely linked with forensic anthropology-the identification of unidentified bodies. Specifically, biohistorians are concerned with reconstructing life histories of famous individuals or individuals associated with well-known historical events. For example, the exhumation and analysis of Tycho Brahe's remains was at least in part to determine if the sixteenthcentury astronomer had been murdered (Rasmussen et al. 2013). Other recent examples include identifying the body of St. Paul (Mihanović et al. 2017) and examining the life history of famous castrato singer Farinelli (Belcastro et al. 2011). Whether or not all such studies have a scientific rationale, this avenue of inquiry can provide important methods drawn from forensic anthropology as well as powerful examples of life histories reconstructed from physical evidence in skeletal remains.

\section{Human Lives and Biographies as a Research Subject in Other Fields}

The narrative study of a life is a qualitative method with many forms, including life writing, biographies, life histories, case studies, autobiographies, and memoirs (Harrison 2008; Smith 1994). Disciplines across the social sciences, humanities, and biomedicine approach individual lives and the lived experience to understand how individuals engage in and perceive their social worlds. Disciplinary boundaries are somewhat fuzzy, and definitions of methods and terminology are not always discrete. The fields and research areas that explore narrative and biography are briefly addressed here with an eye to how they approach and represent individual lives.

Biography as a historical method or research perspective has seen renewed interest in recent decades (Renders et al. 2017). In fact, many historians argue that a "biographical turn" commenced in the early 2000 s as a reaction to statistical and analytical methods of historiography and as a critique of "grand narratives" (Caine 2010; Possing 2015, 2017) in a way that parallels transformations within bioarchaeology. Importantly, biography plays a significant role in popular history, engaging with the public in an accessible, narrative form. However, the place of biographical studies has long been a debate among historians. Critics of historical biography argue that investigating individuals' lives adds little to understandings of history (Kessler-Harris 2009; Possing 2015). Additionally, the textual record is strongly biased toward famous or extraordinary people, making biographies of ordinary people difficult to write (Salvatore 2004). Historians approach biographies in two main ways: as a lens through which to access larger events and processes, or with a focus on a particular life, with limited larger context. Recent proponents of historical biography argue that, in using a critical narrative approach, biographies can move between individual lives and broader historical questions (Kessler-Harris 2009; Meister 2017; Renders et al. 2017). The narrative approach of microhistory has offered some insights for historical biographers seeking to bridge these scales of analysis. Microhistorians argue that examining objects on a small, intimate scale will reveal previously overlooked phenomena and provide connections to wider historical processes (Ginzburg 2014; Levi 2001; Meister 2017).

Anthropology has a long history of engaging with life histories and narratives, although with a less explicit reliance on biographical methods. Anthropologists have explored the concept of life histories through oral narratives (Angrosino 2007; Langness and Frank 1981) as well as the cultural lives of things (Appadurai 1986; Hoskins 1996; Kopytoff 1986). This tradition also includes the biography of individuals from an anthropological perspective, involving an ethnographic focus on the hyper-local (Herzfeld 1998; Kristmundsdottir 2006) as well as the anthropologist as autobiographer (Okely and Callaway 1992). Life-course and lifehistory perspectives, emerging from behavioral studies, biology, and evolutionary theory, have also influenced how biological anthropologists approach composite life narratives in terms of the timing of life events, 
fertility, and mortality (Elder et al. 2003; Hill and Kaplan 1999).

Biographical methods have been used more explicitly in archaeology as a way to approach people through their material worlds (Gilchrist 2012; Meskell and Joyce 2003; Mytum 2010) and to examine the "life" of artifacts (Beaudry 2011; Gosden and Marshall 1999; Joy 2009; Meskell 2004). Indeed, Mytum (2010:242) explains that archaeological biographies are typically "not life-long biographies of individuals, but insights into particular places, associations and events for which the data is rich enough to allow such a construction." Artifact biographies are necessarily relational, tacking between humans, things, spaces, and technologies to examine use-lives or the relationships between people and objects. These small-scale biographies might be contrasted with life-history approaches concerned with larger-scale and long-term changes in artifacts and technologies (Joy 2009). Historical archaeologists, in particular, have explored microhistorical representations of site histories, artifact biographies, and individual lives (Brooks et al. 2008; Huppertz 2010; Janowitz and Dallal 2013).

Qualitative inquiries in sociology, in the form of case studies and life histories, underscore the importance of subjective experience and how the life course is shaped by interrelated social factors (Heinz and Krüger 2001; Possing 2015). A life-course perspective in sociology refers to changes in human lives across time and through social and institutional structures. This approach emphasizes how conditions of early life affect outcomes later in life and the conjunctions of biological, family, cultural, and institutional factors that shape the life course (Gilleard and Higgs 2015; Harrison 2008; Heinz and Krüger 2001; Mayer 2009). Despite a disciplinary emphasis on structures over the individual to form generalizations about society, more recent scholarship has taken seriously how individual cases can be representative and theoretically meaningful (B. Roberts 2002; Rustin 2008). Two currently relevant examples are understanding how men and women follow different career trajectories in spite of attempts to create gender equality and understanding the social consequences of lengthening the human life span. Life-course studies require longitudinal research establishing social structures integrated with individual life histories based on interviews and case studies (Heinz and Krüger 2001). This interplay of micro- and macro-analyses, using both quantitative and qualitative data, is what gives a life-course perspective particular significance across the social sciences.

The case study approach in biomedicine is a research method that allows for "an in-depth, multifaceted understanding of a complex issue in its real-life context" (Crowe et al. 2011:2). A deeply contextualized clinical case provides insights into causality, compounding factors, and the course of intervention. While being criticized for a diminished ability to generalize, case studies are contrasted with (or complement) large-scale research designs that may be unfeasible or unable to account for the complexities of a clinical setting (Crowe et al. 2011). Biography and narrative have been explored in other areas of biomedical research, education, and ethics in the form of illness narratives (Bishop and Sunderland 2013) and narrative medicine (Charon 2001; Morris 2008). According to Charon (2001), the storytelling inherent in clinical medicine links patients, physicians, and students and requires a narrative competence among medical professionals. Narratives of biomedicine can even involve object biographies, as in Nunes et al.'s (2013) depiction of the bacterium Helicobacter pylori as a biomedical entity with a life history. While we have only touched on the many narrative approaches to individual lives, this summary has shown the efficacy of such a perspective across disciplines.

\section{Central Concepts and Methods of Osteobiography}

Approaching life histories from skeletal remains requires attention to several key concepts that shape how we "do" osteobiographies. The first is the centrality of the body as the locus of experience and biocultural change. As noted above, the body is constantly in a process of becoming, a "work in progress" of both biological and social origin (Ingold 2011; Joyce 2005; Sofaer 2006). Bioarchaeologists rely on the concept of skeletal plasticity to address ways in which social and material worlds shape and inform the biological body (Agarwal 2016; Sofaer 2006). "Plasticity" refers to the capability of the human body to change in response to damage, stress, disease, or degenerative changes. $\mathrm{Bi}$ ological processes unfold in a social environment, influenced by learned action, labor, habits, and events throughout the life course. As the focal point of these transformations, the body itself is an intersection of multiple processes, materials, and histories (Novak 2017a, 2017b). In fact, one might argue that the body "embodies" history. We see differences in skeletal bodies from different time periods and geographies that reflect how social and environmental histories are enacted on and through the body (Robb and Harris 2013)

Characteristics of the body, such as age, sex/gender, and health, are based on a lifetime of culturally negotiated activities. Osteobiography must attend to the biosocial changes of the body over time, reconciling biological age estimations with the culturally 
contextualized understandings of age as social process (Agarwal 2016; Appleby 2011; Gilchrist 2012; Sofaer 2011) as well as integrating categories of biological sex with the diverse lived experiences of gender (Geller 2016; Sofaer 2006; Sofaer and Sørensen 2013). The intersections between these aspects of identity are particularly rich analytical nodes for bioarchaeology. By "shifting the focus from identity to identities" (Byrnes 2017:204), we begin to see how multiple components of social identity become embodied. Dynamics of class, power, age, disability, gender, and ancestry gather together at the site of the body, creating particular configurations and possibilities (Boutin 2016; Byrnes 2017; Byrnes and Muller 2017; Geller 2016).

At the heart of osteobiography, as with all forms of narrative, are the concepts of time, scale, and sequence. As bioarchaeologists, we often give primacy to chronometric time in our quest to estimate age at death from skeletal indicators. However, it is arguable that social temporalities are of greater import when considering narrative life histories. The life-course model "situates the human life span within social measures of time" (Gilchrist 2004:156). Such a conceptualization provides the body with a cultural biography of normative (and alternative) stages (Robb 2002). This social temporality is entangled with other temporal scales from individual to cosmological measures that link generations and other intersections of identity. Thinking about time as multi-scalar allows us to move analytically between individuals and populations, building narratives through this dialogue and developing sequences of individual life histories. What ultimately differentiates osteobiography from other ways of interpreting bioarchaeological data are (a) the focus upon the individual life span as the unit of analysis and (b) arranging data within the life span to form a temporally integrated sequence, in which earlier processes or events cause or form a context for later ones. These factors translate into several specific approaches. Some are straightforward and well developed; others are at the frontiers of current methods and need further development.

\section{Working from samples to individuals and back again}

Bioarchaeology traditionally regards individuals simply as constituents of samples; what matters is the aggregate characteristics of the whole group, often expressed in terms of a graph showing general trends, a correlation coefficient, or summary statistics such as averages and standard deviations. It is assumed that all samples inherently vary, and the variation displayed by a single point will be of minimal analytical purchase or interest. There has been little attention to asking why a specific data point falls where it does, and how this position can be understood in terms of its other characteristics. Indeed, given that most studies reduce the available data to only a handful of variables, it is often actually impossible to pose such questions.

Clearly, we can only understand an individual data point by starting from an understanding of the whole sample and its general characteristics. What is normal or exceptional, local or exotic, coherent or discordant can only be assessed against a wider context. This observation is true not only in terms of biological variation but in social variation as well; individual identities conform to and work against normatively constituted identities such as gender and age, and all societies also understand the life span in terms of a normative biography. Such a biography is divided into stages, each of which has its own characteristics. Methodologically, this means that osteobiography is interdependent with traditional bioarchaeology: to construct osteobiographies, we have to continually work back and forth from the general characteristics of the whole sample to the individuating variation of a specific person.

\section{Layering different kinds of data}

To build an osteobiography, we need to layer as many kinds of data as possible to include a critical density of information about our "person of interest." This process allows us to juxtapose aspects of someone's life and ask new questions about them. For instance, did early health episodes have an effect upon their working lives? Does their burial treatment relate to their health status or appearance? Is an anomalous age estimate related to signs of pathology or intense physical activity? As the osteobiographies to date (see literature review above) and the articles in this collection suggest, there is a core of common elements that often recur.

- Context: the skeleton's broader archaeological context, including mortuary environment and other relevant information (as well as historical or textual information, where it is available).

- Demography: the individual's age at death, and biological sex.

- Genetic variation: as available from metric and nonmetric variation, biodistance data, and analysis of aDNA, providing not only an idea of affinities within a local gene pool but much other information besides (e.g., SNPs revealing probable eye and hair color).

- Health: the individual's health, as inferred from palaeopathology and, increasingly, analysis of pathogen aDNA. This assessment includes not only the possible health conditions the individual experienced 
but also their experiential consequences (pain, suffering, disability, changes to appearance or social categorization).

- Diet: as revealed from skeletal and dental data such as dental disease, and from isotopic $(\mathrm{C}, \mathrm{N})$ enrichment ratios. A comparison of isotopes from tissues forming in childhood (particularly teeth), in adulthood (such as slow turn-over cortical bone), and relatively soon before death (such as ribs, tissue, or hair) may reveal changes in diet throughout the life span.

- Mobility: accessible through isotopic ratios (e.g., Sr, $\mathrm{O}$ and $\mathrm{Pb}$ ) that may reveal the individual's environmental context at moments when specific tissues were forming. Comparison with others in the sample and between samples may suggest how much a person moved during his or her life.

- Signs of activity, use, and degeneration: an amorphous category of data that always needs careful contextualization within a particular sample, sex, and age range. However, characteristics such as size, body shape and robusticity, laterality, local or general wear and tear, and idiosyncratic development of particular complexes of muscles may reveal habitual activities or socially salient aspects of the individual's appearance, identity, or life course.

- Bodily modification: including cranial shaping, trepanation, and dental ablation or modification.

- Deathways and postmortem history: including how the remains were processed, curated, circulated, and/or deposited. These characteristics may relate not only to the person's identity or circumstances of death but also to what extent the person was regarded as an active social agent following biological death.

This list of data is long. In our experience, for any given individual, most of these data will fall more or less within the "unremarkable" range, and it will only be a few points, or combinations of points, that will highlight the most salient individuating aspects of an osteobiographical life narrative (see Robb et al., this issue).

One consequence of this array of data is that osteobiography may involve different working practices than standard bioarchaeology (as in the traditional model of a lone researcher collecting one or two kinds of data for a specialized study). There can be no standard "package" of data constituting the raw materials for an osteobiography; the available data depend upon many factors, such as how well preserved the skeletal remains are, the state of documentation (particularly if one is using published "legacy" data or old collections that may lack contextual information), the available expertise and funding, and so on. Even so, it is clear that composing an osteobiography requires many different areas of expertise. It may also require considerable funding; while obtaining isotopic data or
aDNA data for one individual may not be too costly, obtaining enough comparative data to put that person in context may cost a lot more. While a lot of the data above could be gathered by an experienced osteologist working alone, the most detailed osteobiographies will typically be generated by a well-funded, relatively large interdisciplinary team.

\section{Sequence}

With the systematic analysis of sequence, we move from things bioarchaeologists largely are doing already to frontiers that need further development. Arranging data in temporal sequence is essential to biography. Earlier events and conditions channel later ones and influence the possible outcomes the body can take. This configuration has a number of distinct ramifications. Bodily processes such as growth, health, and aging create contexts for what happens next. A well-known example is childhood stress contributing to poorer health later in life. Some studies have shown that individuals with enamel defects occurring in early childhood are more likely to die at earlier ages, suggesting that health issues in childhood can affect mortality rates throughout the life course (Armelagos et al. 2009; Boldsen 2007; Miszkiewicz 2015). The best pioneered approach is understanding biological sequence by comparing data from tissues that form at different points in life, typically childhood (from dental data, but also potentially by stature and other evidence of childhood health), adulthood (from slowly replaced bone tissue such as long bone cortical bone) and the last decade or so before death (from quickly replaced bone tissue such as ribs). The same principle can be used to reconstruct micro-sequences of isotopic data during childhood by micro-sampling dental enamel formed throughout various moments of growth.

Such concepts could be developed further. For instance, many pathological lesions, such as trauma and periosteal bone growth, can be classified as active or healed at the time of death, giving information on health changes within an interval of a year or more before death. We can also classify health conditions as having episodic effects, ongoing effects, or permanent effects. For instance, a well-preserved dentition may show evidence of complex sequences (a set of molars on one side wears and decays within the interval between full eruption and some years before death, their alveoli resorb, and we can see accelerated or idiosyncratic wear on the remaining antimeres). It may be possible to build quite a complex internal chronology from a well-aged and "busy" skeleton.

A different aspect of sequence concerns how our "person of interest" relates to historical context. Traditionally, archaeologists have been satisfied with 
relatively loose chronological bracketing; a radiocarbon date with a margin of error of 50-100 years allows us to place a burial within most archaeological periods, so that we can regard someone as a generic representative of, say, the Neolithic, the Early Mississippian, and so forth. But a combination of careful use of archaeological context and Bayesian calibration can get chronological resolution down to the generational level, allowing us to compose nearly real-time "histories" (Bayliss and Whittle 2007). In some cases, particularly in historical bioarchaeology, we can tease out a community of people who were alive contemporaneously (Novak 2017a). Knowing a date of death and an approximate life span, can we understand what events someone may have lived through and how they may have affected their life story? Sequences can also be extended intergenerationally, highlighting the relational nature of the life course. For example, Gowland (2015) points out the heritability of poor health and the impact of the maternal environment on early (and later) life in a bioarchaeological context.

\section{Data analysis}

Perhaps the least-developed methodological aspect of osteobiography concerns how we use data, and here we only mention some possibilities for development. Standard statistical methods can be used to establish correlations between different skeletal data, and if these data can also be put into sequence we may be able to build causal narratives. For instance, such a sequence may show how early life experiences relate to a priori social categorizations on one hand and to subsequent life events on the other. Techniques such as risk analysis may provide additional ways to express such relationships that focus less upon aggregate samples and more upon the probabilities of individual life contingencies. Finally, we need to develop new ways of representing data to help us spot patterns and important variations. Sociologists studying variation in the life course use techniques such as network analysis and cluster analysis to show how individual lives conform to or depart from normative patterns and are channeled by important life events. Even at the level of simple graphs and diagrams, finding ways to convey information such as how skeletal data relate to how long someone lived would transform our ability to visualize patterns in human lives (see Robb, this issue).

\section{Some Frontiers for Osteobiography}

In thinking about new frontiers for osteobiography, we put forward some theoretical issues to consider. For example, what is a life? As the unit of our analysis in an osteobiography, what do we mean by a "life" history? A key consideration is the social agency of the dead. When bioarchaeology is brought into conversation with taphonomy, it is possible to extend biography from (before the) cradle to (after the) grave. Additionally, a common assumption in osteobiography is that "individuals" are equated with skeletons. This identification creates an inherent assumption of a bounded entity, rather than one that is relational, material, and contingent. We must ask ourselves, what is the entity? Are they living/dead, human/non-human, prehuman, posthuman? Bodies can also be subject to fragmentation, made partible or even aggregate. Obvious examples emerge from burial taphonomy such as permeable Maya bodies (Duncan and Schwarz 2013; Geller 2012) and medieval saints' relics (Robb 2013), as well as modern examples such as organ transplants and body donation systems.

Another important consideration is the relationship between material things and the body. If we take the body to be material culture, how should osteobiography include things? Other materials might come into articulation with the body-many with their own material biographies-such as prosthetic devices, dental fillings, tattoo ink, and so forth. The question of what things is also significant: the fact that skeletal remains are often found in deliberate burial contexts means that we create an implicit hierarchy with grave goods because of their proximity to the skeleton. But what other objects are important in creating an osteobiography, and how do we bring these into a conversation? The materiality of things is particularly emergent when considering weak-agency people, such as children and the elderly, leading to a focus on material culture as part of the construction of identity for these individuals as well as the limitations of the body itself.

Recent bioarchaeological projects have pushed boundaries of sex and gender and have examined how these aspects of identity develop in the course of social life (Geller 2016). How do we relate evidence of biological and social variation, particularly when it is discrepant? When we find a Viking-period woman buried with weapons (Hedenstierna-Jonson et al. 2017), do we assume (perhaps influenced by today's gender attitudes) that binary gender based on biological sex was normal in the past, so that there must be some sexing error and "she" must really be male? Or that being a warrior was not a gendered activity? Or that Viking-period gender was not in fact binary? Other frontiers include challenging the concept of a skeletal "population" as representing synchronous lives in temporal continuity (Novak 2017a). Is it possible to identify individuals who were alive at the same time through probability-based analysis or through 
the integration of other types of evidence (including cemetery records and other historical sources)? We may also consider new approaches to data analysis and aggregating lives, such as developing comparative shapes of life courses using multivariate analyses.

\section{Osteobiography and Archaeological Ethics}

Osteobiography, like all methods of conceptualization, has an ethical and political dimension rooted in our own situatedness in social relations. Geller (this issue) raises some classic ethical dilemmas, particularly in formerly colonial settings and arenas in which knowledge is depersonalized and commercialized. But osteobiography raises much broader ethical dilemmas as well, as it provides a powerful tool for mobilizing the imagination and engaging with our publics.

The most obvious ethical dimension concerns the politics of osteobiography. In creating osteobiographies, we may effectively be deputizing a few individuals to stand for an entire place or period in our and the public's imaginations. As feminist critics since Conkey and Spector (1984) have noted, peopling the past is a politically loaded act. How do we choose the subjects for osteobiography? Do we seek to represent "typical" lives? "Interesting" lives (and what makes a life "interesting")? "Invisible" lives? "Alternative" lives? Do we choose the 99 slaves who conformed and were worked to death, or the one who resisted? The Roman "Bangle Lady" originated in North Africa and was buried in York, underlining the multicultural and mobile nature of Roman society (Leach et al. 2010). But most of her cohort were much more local. Should we aim the osteobiographical spotlight at her or at one of them? At an even deeper layer of ontological assumptions, how do our life narratives impose our own concepts of animacy and humanness on past societies? Should osteobiographies make the past comprehensibly familiar or challengingly alien? How familiar is too familiar, taking the easy way out?

The other ethical dimension concerns the responsibilities of knowledge. Take the question of naming anonymous skeletons-something on which there is a surprising level of deeply felt difference of opinion. On one hand, names humanize skeletons; both we and the public understand and relate to "Jonathan" or "Flavia" differently than to "Individual 247" or "Context 958." But in giving people names of our own invention, are we humanizing them in a space all parties understand as imaginatively constituted, or are we claiming knowledge we cannot actually discern? Does humanizing concreteness trump literal facticity in some contexts? Or can we find ways offinessing the issue-giving people generic names such as "the ship's carpenter" (as in the Mary Rose and Vasa museums), or using typography to highlight the different bases of imagination and fact? Our ethical obligations extend not only toward our professional responsibilities to create knowledge and our duty toward the public who trust our authority, but also to the ancient people we study.

\section{Conclusions}

Human lives are not disconnected facts and data points; they have a structure, and they also have a cultural interpretation of that structure. Bioarchaeology allows us to glimpse the human experience of living in past societies, and osteobiography offers a particularly compelling way to approach the forms these lives can take. The narrative of a life can be understood as a building block of social history, allowing our scales of analysis to shift between big questions of populations and social change, on the one hand, and the events and contingencies at work across a single life, on the other. Indeed, osteobiography has raised important questions in some areas of archaeology; for example, it is biographies such as the Egtved Girl (Frei et al. 2015) that have directed attention to the role of high-status women in Bronze Age Europe.

The articles in this issue draw on a range of topics at the forefront of bioarchaeology, bringing new theoretical and methodological approaches to bear on osteobiography. Robb et al. compare the analytical possibilities of textual biography and skeletal biography through two individuals from thirteenth-century Cambridge, England. The archival traces of ordinary people are more biased by socioeconomics and gender than the full suite of osteological, molecular, and reconstructive techniques afforded by osteobiography. Appleby incorporates theories of local biologies and relational personhood in forming an osteobiography of Richard III. She argues that Richard's bone chemistry reflects the biosocial consequences of his negotiation of kingship through particular consumption practices. Hosek marries osteobiography with a microhistorical approach to address issues of scale and relationality in individual life histories. She presents two osteobiographies from early medieval Bohemia and shows how these lives articulate with large-scale historical processes. Robb uses aggregate osteobiographies to outline the courses an individual life might take. The ensuing life-course maps show how pathways might diverge or intertwine based on biological and social differences such as gender and age. Boutin and Callahan use social psychology to explore how osteobiography might be used in public outreach. They show how different types of osteobiographical narratives play a role in humanizing people from the 
past and affect how they are viewed by modern audiences. Finally, Geller proposes a "bioethos" that incorporates ethical questions into osteobiographical research design. Through the examples of Kennewick Man/Ancient One and HeLa/Henrietta Lacks, she explores how naming, facial reconstruction, and issues of ownership complicate the narratives we develop about human remains.

A criticism of osteobiography (and case studies more broadly) that we raised earlier is that one case cannot prove anything. While this statement might be true, both previous osteobiographies and the articles in this issue demonstrate that upholding generalizations is not the real goal of such an approach. Osteobiography allows for an understanding of variability in past lives that would otherwise be lost in the search for $p$-values. In contrast to the tyranny of the average, but also in conjunction with it, osteobiography can reveal exceptional people or unusual lives that risk being smoothed out in a population analysis. Alternatively, in illustrating the life of a typical individual, osteobiography might better humanize population statistics. Perhaps even more significantly, osteobiography provides a way to sequence and layer skeletal data into richly contextualized life histories, drawing attention the role of pathway and contingency in the development of a life. We hope that this overview and the following contributions expand the possibilities of osteobiography as a conceptual tool for bioarchaeology, opening new directions for telling stories with skeletal remains.

\section{Postscript}

Few scholars discuss osteobiography without a nod to Frank Saul and his foundational work on the concept with his wife, Julie Mather Saul. Indeed, when we first conceptualized a conference symposium we asked ourselves, where has osteobiography gone since Saul and Saul (1989), and where does it go next? The passing of Frank Saul in June 2018 coincided with the submission of these articles. We would like to acknowledge here his many contributions to Maya archaeology, forensic anthropology, and bioarchaeology. We hope that this special issue serves as a recognition of his lasting impact on how we approach life histories through the skeletal body.

\section{Acknowledgments}

The authors would like to thank the editors of Bioarchaeology International for their guidance and for the opportunity to put together this special issue. We would also like to thank the participants of the Bodies as Narratives symposium at the 2017 Society for American Archaeology meeting in Vancouver, British Columbia, for their lively discussion and insights into the future of osteobiography. We are grateful to Brenda Baker and to three anonymous reviewers for thoughtful comments that have improved this paper.

\section{References Cited}

Agarwal, Sabrina C. 2012. The past of sex, gender, and health: Bioarchaeology of the aging skeleton. American Anthropologist 114(2):322-335. DOI: 10.1111/j.1548-1433.2012.01428.x.

Agarwal, Sabrina C. 2016. Bone morphologies and histories: Life course approaches in bioarchaeology. American Journal of Physical Anthropology Supplement: Yearbook of Physical Anthropology 159(S61):130-149. DOI: 10.1002/ajpa.22905.

Agarwal, Sabrina C., and Bonnie A. Glencross, eds. 2011. Social Bioarchaeology. Wiley-Blackwell, London. DOI: 10.1002/9781 444390537.

Angrosino, Michael V. 2007. Conducting a life history interview. In Doing Cultural Anthropology: Projects for Ethnographic Data Collection, edited by Michael V. Angrosino. 2nd ed. Waveland Press, Long Grove, IL, pp. 33-44.

Appadurai, Arjun. 1986. The Social Life of Things: Commodities in Cultural Perspective. Cambridge University Press, Cambridge. DOI: 10.1017/cbo9780511819582.

Appleby, Joanna E. P. 2011. Why we need an archaeology of old age, and a suggested approach. Norwegian Archaeological Review 43(2):145-168. DOI: 10.1080/00293652.2010.531582.

Appleby, Joanna, Guy N. Rutty, Sarah V. Hainsworth, Robert C. Woosnam-Savage, Bruno Morgan, Alison Brough, Richard W. Earp, Claire Robinson, Turi E. King, Mathew Morris, and Richard Buckley. 2015. Perimortem trauma in King Richard III: A skeletal analysis. Lancet 385(9964):253-259. DOI: 10.1016 /S0140-6736(14)60804-7.

Armelagos, George J., Alan H. Goodman, Kristin N. Harper, and Michael L. Blakey. 2009. Enamel hypoplasia and early mortality: Bioarcheological support for the Barker Hypothesis. Evolutionary Anthropology 18(6):261-271. DOI: 10.1002/evan.20239.

Baadsgaard, Aubrey, Alexis T. Boutin, and Jane E. Buikstra, eds. 2012. Breathing New Life into the Evidence of Death: Contemporary Approaches to Bioarchaeology. School for Advanced Research Press, Santa Fe.

Baker, Brenda J., and Sabrina C. Agarwal. 2017. Stronger together: Advancing a global bioarchaeology. Bioarchaeology International 1(1-2):1-18. DOI: 10.5744/bi.2017.1005.

Baker, Brenda J., and Katelyn L. Bolhofner. 2014. Biological and social implications of a medieval burial from Cyprus for understanding leprosy in the past. International Journal of Paleopathology 4:17-24. DOI: 10.1016/j.ijpp.2013.08.006.

Barker, David J., Johan G. Eriksson, Tom Forsén, and Clive Osmond. 2002. Fetal origins of adult disease: Strength of effects and biological basis. International Journal of Epidemiology 31(6):1235-1239. DOI: 10.1093/ije/31.6.1235.

Bayliss, Alex, and Alisdair Whittle, eds. 2007. Histories of the dead: Building chronologies for five southern British long barrows [Special issue]. Cambridge Archaeological Journal 17(S1).

Beauchesne, Patrick, and Sabrina C. Agarwal, eds. 2018. Children and Childhood in Bioarchaeology. Bioarchaeological Interpretations of the Human Past: Local, Regional, and Global Perspectives. University Press of Florida, Gainesville. 
Beaudry, Mary C. 2011. Stitching women's lives: Interpreting the artifacts of sewing and needlework. In Interpreting the Early Modern World: Transatlantic Perspectives, edited by Mary C. Beaudry and James Symonds. Springer, New York, pp. 143-158.

Belcastro, Maria Giovanna, Antonio Todero, Gino Fornaciari, and Valentina Mariotti. 2011. Hyperostosis frontalis interna (HFI) and castration: The case of the famous singer Farinelli (1705-1782). Journal of Anatomy 219(5):632-637. DOI: 10.1111/j .1469-7580.2011.01413.x.

Bishop, Jeffery, and Naomi Sunderland. 2013. Living with the label "disability": Personal narrative as a resource for responsive and informed practice in biomedicine and bioethics. Narrative Inquiry in Bioethics 3(3):183-221. DOI: 10.1353/nib.2013.0067.

Boldsen, Jesper L. 2007. Early childhood stress and adult age mortality-A study of dental enamel hypoplasia in the medieval Danish village of Tirup. American Journal of Physical Anthropology 132(1):59-66. DOI: 10.1002/ajpa.20467.

Boutin, Alexis T. 2011. Crafting a bioarchaeology of personhood: Osteobiographical narratives from Alalakh. In Breathing New Life into the Evidence of Death, edited by Aubrey Baadsgaard, Alexis T. Boutin, and Jane E. Buikstra. School for Advanced Research Press, Santa Fe, pp. 109-133.

Boutin, Alexis T. 2012. Written in stone, written in bone: The osteobiography of a Bronze Age craftsman from Alalakh. In The Bioarchaeology of Individuals, edited by Ann L. W. Stodder and Ann M. Palkovich. University Press of Florida, Gainesville, pp. 193-214.

Boutin, Alexis T. 2016. Exploring the social construction of disability in the past: An application of the bioarchaeology of personhood model to a pathological skeleton from ancient Bahrain. International Journal of Paleopathology 12: 17-28. DOI: 10.1016/j.ijpp.2015.10.005.

Brooks James F., Christopher R. N. DeCorse, and John Walton, eds. 2008. Small Worlds: Method, Meaning, \& Narrative in Microhistory. School for Advanced Research Press, Santa Fe.

Buikstra, Jane E. 1976. Hopewell in the Lower Illinois Valley. Northwestern Archeological Program, Scientific Series 2. Northwestern University, Evanston.

Buikstra, Jane E. 2006. A historical introduction. In Bioarchaeology: The Contextual Analysis of Human Remains, edited by Jane E. Buikstra and Lane A. Beck. Elsevier, Amsterdam, pp. 7-26.

Buikstra, Jane E., Aubrey Baadsgaard, and Alexis T. Boutin. 2011. Introduction. In Breathing New Life into Evidence of Death: Contemporary Approaches to Bioarchaeology, edited by Aubrey Baadsgaard, Alexis T. Boutin, and Jane E. Buikstra. School for Advanced Research Press, Santa Fe, pp. 3-28.

Buikstra, Jane E., and Rachel E. Scott. 2009. Identity formation: Communities and individuals. In Bioarchaeology and Identity in the Americas, edited by Kelly J. Knudson and Christopher M. Stojanowski. University Press of Florida, Gainesville, pp. 24-55.

Byrnes, Jennifer F. 2017. Injuries, impairment, and intersecting identities: The poor in Buffalo, NY 1851-1913. In Bioarchaeology of Impairment and Disability: Theoretical, Ethnohistorical, and Methodological Perspectives, edited by Jennifer F. Byrnes and Jennifer L. Muller. Springer, New York, pp. 201-222.

Byrnes, Jennifer F., and Jennifer L. Muller, eds. 2017. Bioarchaeology of Impairment and Disability: Theoretical, Ethnohistorical, and Methodological Perspectives. Springer, New York. DOI: 10.1007/978-3-319-56949-9.

Caine, Barbara. 2010. Biography and History. Palgrave MacMillan, New York. DOI: 10.1007/978-1-137-10740-4.

Cave, Christine, and Marc Oxenham. 2016. Identification of the archaeological "invisible elderly": An approach illustrated with an Anglo-Saxon example. International Journal of Osteoarchaeology 26(1):163-175. DOI: 10.1002/oa.2408.

Charon, Rita. 2001. Narrative medicine: A model for empathy, reflection, profession, and trust. Journal of the American Medical Association 286(15):1897-1902. DOI: 10.1001/jama.286.15 .1897 .

Conkey, Margaret W., and Janet D. Spector. 1984. Archaeology and the study of gender. Advances in Archaeological Method and Theory 7:1-38. DOI: 10.1016/b978-0-12-003107-8.50006-2.

Couoh, Lourdes R. 2015. Bioarchaeological analysis of a royal burial from the oldest Maya tomb in Palenque, Mexico. International Journal of Osteoarchaeology 25(5):711-721. DOI: 10 $.1002 /$ oa.2338.

Crowe, Sarah, Kathrin Cresswell, Ann Robertson, Guro Huby, Anthony Avery, and Aziz Sheikh. 2011. The case study approach. BMC Medical Research Methodology 11(100). DOI: 10 $.1186 / 1471-2288-11-100$.

Duncan, William N., and Kevin R. Schwarz. 2013. Partible, permeable, and relational bodies in a Maya mass grave. In Commingled and Disarticulated Human Remains: Working toward Improved Theory, Method, and Data, edited by Anna J. Osterholtz, Kathryn M. Baustian, and Debra L. Martin. Springer, New York, pp. 149-170.

Elder, Glen H., Jr., Monica Kirkpatrick Johnson, and Robert Crosnoe. 2003. The emergence and development of life course theory. In Handbook of the Life Course, edited by Jeylan T. Mortimer and Michael J. Shanahan. Springer, New York, pp. 3-19.

Fay, Isla. 2006. Text, space and evidence of human remains in English late medieval and Tudor disease culture: Some problems and possibilities. In Social Archaeology of Funerary Remains, edited by Rebecca Gowland and Christopher Knüsel. Oxbow Books, Oxford, pp. 190-208.

Frei, Karin Margarita, Ulla Mannering, Kristian Kristiansen, Morten E. Allentoft, Andrew S. Wilson, Irene Skals, Silvana Tridico, Marie Louise Nosch, Eske Willerslev, Leon Clarke, and Robert Frei. 2015. Tracing the dynamic life story of a Bronze Age female. Scientific Reports 5:10431. DOI: 10.1038/srep10431.

Frei, Karin Margarita, Chiara Villa, Marie Louise Jørkov, Morten E. Allentoft, Flemming Kaul, Per Ethelberg, Samantha S. Reiter, Andrew S. Wilson, Michelle Taube, Jesper Olsen, Niels Lynnerup, Eske Willerslev, Kristian Kristiansen, and Robert Frei. 2017. A matter of months: High precision migration chronology of a Bronze Age female. PLOS One 12(6):e0178834. DOI: 10.1371/journal.pone.0178834.

Geller, Pamela. 2012. From cradle to grave and beyond: A Maya life and death. In The Bioarchaeology of Individuals, edited by Ann L. W. Stodder and Ann M. Palkovich. University Press of Florida, Gainesville, pp. 255-270.

Geller, Pamela L. 2014. Sedimenting social identity: The practice of pre-Columbian Maya body partibility. In The Bioarchaeology of Space and Place: Ideology, Power, and Meaning in Maya Mortuary Contexts, edited by Gabriel D. Wrobel. Springer, New York, pp. 15-38.

Geller, Pamela L. 2016. The Bioarchaeology of Socio-Sexual Lives: Queering Common Sense About Sex, Gender, and Sexuality. Springer, New York. DOI: 10.1007/978-3-319-40995-5.

Gilchrist, Roberta. 2004. Archaeology and the life course: A time and a place for gender. In A Companion to Social Archaeology, edited by Lynn Meskell and Robert W. Preucel. Blackwell, Oxford, pp. 142-160.

Gilchrist, Roberta. 2012. Medieval Life: Archaeology and the Life Course. The Boydell Press, Woodbridge, Suffolk, UK.

Gilleard, Chris, and Paul Higgs. 2015. Connecting life span development with the sociology of the life course: A new direction. Sociology 50(2):301-315. DOI: 10.1177/0038038515577906. 
Ginzburg, Carlo. 2014. Microhistory: Two or three things that I know about it. In Theoretical Discussions of Biography: Approaches from History, Microhistory, and Life Writing, edited by Hans Renders and Binne De Haan. Brill, Leiden, pp. 139-166.

Gosden, Chris, and Yvonne Marshall. 1999. The cultural biography of objects. World Archaeology 31:169-178. DOI: 10.1080 /00438243.1999.9980439.

Gowland, Rebecca L. 2015. Entangled lives: Implications of the developmental origins of health and disease hypothesis for bioarchaeology and the life course. American Journal of Physical Anthropology 158(4):530-540. DOI: 10.1002/ajpa.22820.

Gowland, Rebecca, and Chris Knüsel, eds. 2006. Social Archaeology of Funerary Remains. Oxbow, Oxford.

Hamre, Stian Suppersberger, Geir Atle Ersland, Valérie Daux, Walther Parson, and Caroline Wilkinson. 2017. Three individuals, three stories, three burials from medieval Trondheim, Norway. PLOS One 12(7):e0180277. DOI: 10.1371/journal.pone.0180277.

Harrison, Barbara. 2008. Editors' introduction: Researching lives and the lived experience. In Life Story Research, edited by Barbara Harrison. Sage, London, pp. xxi-xlxi.

Hawkey, Diane E. 1998. Disability, compassion, and the skeletal record: Using musculoskeletal stress markers (MSM) to construct an osteobiography from early New Mexico. International Journal of Osteoarchaeology 8(5):326-340. DOI: 10.1002 /(SICI)1099-1212(1998090)8:5<326::AID-OA437>3.0.CO;2-W.

Hedenstierna-Jonson, Charlotte, Anna Kjellström, Torun Zachrisson, Maja Krzewinńka, Veronica Sobrado, Neil Price, Torsten Günther, Mattias Jakobsson, Anders Götherstrom, and Jan Storå. 2017. A female Viking warrior confirmed by genomics. American Journal of Physical Anthropology 164(4):853-860. DOI: 10.1002/ajpa.23308.

Heinz, Walter R., and Helga Krüger. 2001. Life course: Innovations and challenges for social research. Current Sociology 49(2):29-45. DOI: 10.1177/0011392101049002004.

Herzfeld, Michael. 1998. Portrait of a Greek Imagination: An Ethnographic Biography of Andreas Nenedakis. University of Chicago Press, Chicago.

Hill, Kim, and Hillard Kaplan. 1999. Life history traits in humans: Theory and empirical studies. Annual Review of Anthropology 28:397-430. DOI: 10.1146/annurev.anthro.28.1.397.

Hoskins, Janet. 1996. Biographical Objects: How Things Tell the Stories of People's Lives. Routledge, London. DOI: 10.4324 19781315022598.

Huppertz, Wim. 2010. Micro history, archaeology and the study of housing culture: Some thoughts on archaeological and historical data from a cesspit in 17th-century Breda. In Exchanging Medieval Material Culture, edited by Koen de Groote, Dries Tys, and Marnix Pieters. Vlaams Institute, Brussels, pp. 279-284.

Ingold, Tim. 2011. Being Alive: Essays on Movement, Knowledge and Description. Routledge, London. DOI: 10.4324/9780203818336.

Janowitz, Meta F., and Diane Dallal, eds. 2013. Tales of Gotham: Historical Archaeology, Ethnohistory and Microhistory of New York City. Springer, New York. DOI: 10.1007/978-1-4614-5272-0.

Joy, Judy. 2009. Reinvigorating object biography: Reproducing the drama of object lives. World Archaeology 41(4):540-556. DOI: 10.1080/00438240903345530.

Joyce, Rosemary A. 2005. Archaeology of the body. Annual Review of Anthropology 34:139-158. DOI: 10.1146/annurev.anthro 33.070203.143729.

Kessler-Harris, Alice. 2009. Why biography? The American Historical Review 114(3):625-630. DOI: 10.1086/ahr.114.3.625.

Kieffer, C. L. 2017. Sacrifice of the social outcasts: Two cases of Klippel-Feil syndrome at Midnight Terror Cave, Belize. International Journal of Osteoarchaeology 27(1):45-55. DOI: 10.1002 /oa.2456.
Knudson, Kelly J., and Christopher M. Stojanowski, eds. 2009. Bioarchaeology and Identity in the Americas. University Press of Florida, Gainesville. DOI: 10.5744/florida/9780813036786 .001 .0001 .

Knüsel, Christopher J. 2002. More Circe than Cassandra: The Princess of Vix in ritualized social context. European Journal of Archaeology 5(3):275-308. DOI: 10.1179/eja.2002.5.3.275.

Komar, Debra A., and Jane E. Buikstra. 2008. Forensic Anthropology: Contemporary Theory and Practice. Oxford University Press, New York.

Kopytoff, Igor. 1986. The cultural biography of things: Commoditization as process. In The Social Life of Things: Commodities in Cultural Perspective, edited by Arjun Appadurai. Cambridge University Press, Cambridge, pp. 64-91.

Kristmundsdottir, Sigridur Duna. 2006. Far from the Trobriands: Biography as field. In Locating the Field: Space, Place and Context in Anthropology, edited by Simon Coleman and Peter Collins. Berg, New York, pp. 163-177.

Langness, L. L., and Gelya Frank. 1981. Lives: An Anthropological Approach to Biography. Chandler and Sharp Publishers Inc., Novato, CA.

Leach, Stephany, Hella Eckardt, Carolyn Chenery, Gundula Muldner, and Mary E. Lewis. 2010. A lady of York: Migration, ethnicity and identity in Roman Britain. Antiquity 84(323):131145. DOI: $10.1017 / \mathrm{s} 0003598 \times 00099816$.

Lessa, Andrea, and Niéde Guidon. 2002. Osteobiographic analysis of skeleton I, Sítio Toca dos Coqueiros, Serra da Capivara National Park, Brazil, 11,060 BP: First results. American Journal of Physical Anthropology 118(2):99-110. DOI: 10.1002/ajpa.10084.

Levi, Giovanni. 2001. On microhistory. In New Perspectives on Historical Writing, edited by Peter Burke. Penn State University Press, University Park, pp. 97-119.

Lewis, Mary E. 2007. The Bioarchaeology of Children: Perspectives from Biological and Forensic Anthropology. Cambridge University Press, Cambridge. DOI: 10.1017/cbo9780511542473.

Marsteller, Sara J., Christina Torres-Rouff, and Kelly J. Knudson. 2011. Pre-Columbian Andean sickness ideology and the social experience of leishmaniasis: A contextualized analysis of bioarchaeological and paleopathological data from San Pedro de Atacama, Chile. International Journal of Paleopathology 1(1):24-34. DOI: 10.1016/j.ijpp.2011.02.001.

Mayer, Karl Ulrich. 2009. New directions in life course research. Annual Review of Sociology 35(1):413-433. DOI: 10.1146/annurev .soc.34.040507.134619.

Mayes, Arion T., and Sarah B. Barber. 2008. Osteobiography of a high-status burial from the Lower Río Verde Valley of Oaxaca, Mexico. International Journal of Osteoarchaeology 18(6):573588. DOI: 10.1002/oa.1011.

Mays, Simon, David Roberts, P. Marshall, Alistair W. G. Pike, Vivian van Heekeren, Christopher Bronk Ramsey, Elaine Dunbar, P. Reimer, B. Linscott, Anita Radini, Abigail Daisy Lowe, Adam Ashley Dowle, Camilla Filomena Speller, J. Vallender, and J. Bedford. 2018. Lives before and after Stonehenge: An osteobiographical study of four prehistoric burials recently excavated from the Stonehenge World Heritage Site. Journal of Archaeological Science: Reports 20:692-710. DOI: 10.1016/j .jasrep.2018.06.008.

Meister, Daniel R. 2017. The biographical turn and the case for historical biography. History Compass 16(1):e12436. DOI: 10.1111 /hic3.12436.

Melton, Nigel D., Janet Montgomery, and Christopher J. Knüsel, eds. 2013. Gristhorpe Man: A Life and Death in the Bronze Age. Oxbow Books, Oxford.

Meskell, Lynn. 2004. Object Worlds in Ancient Egypt: Material Biographies Past and Present. Berg, Oxford. 
Meskell, Lynn M., and Rosemary A. Joyce. 2003. Embodied Lives: Figuring Ancient Maya and Egyptian Experience. Routledge, London.

Meyer, Christian, Guido Brandt, Wolfgang Haak, Robert A. Ganslmeier, Harald Meller, and Kurt W. Alt. 2009. The Eulau eulogy: Bioarchaeological interpretation of lethal violence in Corded Ware multiple burials from Saxony-Anhalt, Germany. Journal of Anthropological Archaeology 28(4):412-423.

Mihanović, Frane, Ivan Jerković, Ivana Kružić, Šimun Anđelinović, Stipan Janković, and Željana Bašić. 2017. From biography to osteobiography: An example of anthropological historical identification of the remains of St. Paul. The Anatomical Record 300(9):1535-1546. DOI: 10.1002/ar.23602.

Miszkiewicz, Justyna Jolanta. 2015. Linear enamel hypoplasia and age-at-death at medieval (11th-16th centuries) St. Gregory's priory and cemetery, Canterbury, UK. International Journal of Osteoarchaeology 25(1):79-87. DOI: 10.1002/oa.2265.

Morris, David B. 2008. Narrative medicines: Challenge and resistance. The Permanente Journal 12(1):88-96. DOI: 10.7812/tpp /07-088.

Mytum, Harold. 2010. Ways of writing in post-medieval and historical archaeology: Introducing biography. Post-Medieval Archaeology 44(2):237-254. DOI: 10.1179/174581310x1281007424 6546.

Novak, Shannon A. 2017a. Corporeal congregations and asynchronous lives: Unpacking the pews at Spring Street. American Anthropologist 119(2):236-252. DOI: 10.1111/aman.12883.

Novak, Shannon A. 2017b. Talking heads and other specters of the Mountain Meadows Massacre. In Studies in Forensic Biohistory: Anthropological Perspectives, edited by Christopher M. Stojanowski and William M. Duncan. Cambridge University Press, Cambridge, pp. 167-190.

Nunes, João Arriscado, Tiago Santos Pereira, Oriana Brás, and Ana Raquel Matos. 2013. Biographies of Objects and Narratives of Discovery in the Biomedical Sciences: The Case of the Helicobacter pylori. Centro de Estudos Sociais, Coimbra.

Okely, Judith, and Helen Callaway. 1992. Anthropology and Autobiography. Routledge, New York. DOI: 10.2307/2804550.

Owsley, Douglas W., and Richard L. Jantz, eds. 2014. Kennewick Man: The Scientific Investigation of an Ancient American Skeleton. Texas A\&M University Press, College Station.

Porr, Martin, and Kurt W. Alt. 2006. The burial of Bad Dürrenberg, central Germany: Osteopathology and osteoarchaeology of a late Mesolithic shaman's grave. International Journal of Osteoarchaeology 16(5):395-406. DOI: 10.1002/oa.839.

Possing, Birgitte. 2015. Biography: Historical. In International Encyclopedia of the Social \& Behavioral Sciences, edited by James D. Wright. 2nd ed. Elsevier, Oxford, pp. 644-649. DOI: 10.1016/b978-0-08-097086-8.62132-3.

Possing, Birgitte. 2017. Understanding Biographies: On Biographies in History and Stories in Biography. University Press of Southern Denmark, Odense.

Rasmussen Kaare L., J. Kučera, Lillian Skytte, Jan Kameník, V. Havránek, Jiří Smolík, Petr Velemínský, Niels Lynnerup, Jaroslav Brůžek, and J. Vellevet. 2013. Was he murdered or was he not? Part I: Analyses of mercury in the remains of Tycho Brahe. Archaeometry 55(6):1187-1195. DOI: 10.1111/j.1475-4754.2012.00729.x.

Renders, Hans, Binne de Haan, and Jonne Harmsma. 2017. The Biographical Turn: Lives in History. Routledge, London.

Robb, John. 2002. Time and biography. In Thinking through the Body: Archaeologies of Corporeality, edited by Yannis Hamilakis, Mark Pluciennik, and Sarah Tarlow. Kluwer/Academic, London, pp. 145-163.

Robb, John. 2009. Towards a critical Ötziography: Inventing prehistoric bodies. In Social Bodies, edited by Helen Lambert and Maryon McDonald. Berghan Books, Oxford, pp. 100-128.
Robb, John. 2013. History in the body: The scale of belief. In Big Histories, Human Lives, edited by John Robb and Timothy Pauketat. School for Advanced Research Press, Santa Fe, pp. 77-100.

Robb, John, and Oliver J. T Harris. 2013. The Body in History: Europe from the Paleolithic to the Future. Cambridge University Press, Cambridge.

Roberts, Brian. 2002. Biographical Research. Open University Press, Buckingham.

Roberts, Charlotte A., Anwen Caffell, Kori L. Filipek-Ogden, Rebecca L. Gowland, and Tina Jakob. 2016. "Til poison phosphorous brought them death": A potentially occupationally-related disease in a post-medieval skeleton from north-east England. International Journal of Paleopathology 13:39-48. DOI: 10.1016 /j.ijpp.2015.12.001.

Rühli, Frank J., and Salima Ikram. 2014. Purported medical diagnoses of Pharaoh Tutankhamun, c. 1325 BC. HOMOJournal of Comparative Human Biology 65(1):51-63. DOI: 10 $.1016 /$ j.jchb.2013.08.006.

Rustin, Michael. 2008. New Labour and the theory of globalisation. Critical Social Policy 28(3):273-282. DOI: 10.1177/026101 8308091269.

Salvatore, Nick. 2004. Biography and social history: An intimate relationship. Labour History 87(2):187-192. DOI: 10.2307 127516005.

Saul, Frank P. 1972. The human skeletal remains of Altar de Sacrificios: An osteobiographic analysis. Papers of the Peabody Museum 63(2):3-123.

Saul, Frank P., and Julie Mather Saul. 1989. Osteobiography: A Maya example. In Reconstruction of Life from the Skeleton, edited by Mehmet Y. Iscan and Kenneth A. R. Kennedy. Alan R. Liss, New York, pp. 287-301.

Smith, Louis M. 1994. Biographical method. In Handbook of Qualitative Research, edited by Norman K. Denzin and Yvonna S. Lincoln. Sage, Thousand Oaks, CA, pp. 286-305.

Sofaer, Joanna R. 2006. The Body as Material Culture: A Theoretical Osteoarchaeology. Cambridge University Press, Cambridge. DOI: 10.1017/cbo9780511816666.

Sofaer, Joanna. 2011. Towards a social bioarchaeology of age. In Social Bioarchaeology, edited by Sabrina C. Agarwal and Bonnie A. Glencross. Blackwell, Oxford, pp. 285-311. DOI: 10.1002 19781444390537.ch10.

Sofaer, Joanna, and Marie Louise Stig Sørensen. 2013. Death and gender. In The Oxford Handbook of the Archaeology of Death and Burial, edited by Liv Nilsson Stutz and Sarah Tarlow. Oxford University Press, Oxford, pp. 527-542. DOI: 10.1093 /oxfordhb/9780199569069.013.0029.

Sofaer Derevenski, Joanna. 2000. Rings of life: The role of early metalwork in mediating the gendered life course. World Archaeology 31(3):389-406. DOI: 10.1080/00438240009696928.

Stead, Ian Mathieson, J. B. Bourke, and Don Brothwell, eds. 1986. Lindow Man: The Body in the Bog. British Museum Publications Ltd., London.

Stirland, A. J. 2000. Raising the Dead: The Skeleton Crew of King Henry VIII's Great Ship, the Mary Rose. John Wiley \& Sons, New York.

Stodder, Ann L. W., and Ann M. Palkovich, eds. 2012. The Bioarchaeology of Individuals. University Press of Florida, Gainesville. DOI: 10.5744/florida/9780813038070.001.0001.

Stojanowski, Christopher, and William N. Duncan. 2015. Engaging bodies in the public imagination: Bioarchaeology as social science, science, and humanities. American Journal of Human Biology 27(1):51-60. DOI: 10.1002/ajhb.22522.

Stojanowski, Christopher M., and William N. Duncan. 2017. Studies in Forensic Biohistory: Anthropological Perspectives. Cambridge University Press, Cambridge. DOI: 10.1017/97811 39683531. 
Thompson, Jennifer L., Marta P. Alfonso-Durruty, and John J. Crandall, eds. 2014. Tracing Childhood: Bioarchaeological Investigations of Early Lives in Antiquity. University Press of Florida, Gainesville. DOI: 10.5744/florida/9780813049830.001.0001.

Tilley, Lorna. 2015. Theory and Practice in the Bioarchaeology of Care. Springer, New York. DOI: 10.1007/978-3-319-18860-7.

Tilley, Lorna, and Marc F. Oxenham. 2011. Survival against the odds: Modeling the social implications of care provision to seriously disabled individuals. International Journal of Palaeopathology 1(2):35-42. DOI: 10.1016/j.ijpp.2011.02.003.

Toon, Richard, and Laurie Stone. 2016. Game of thrones: Richard III and the creation of cultural heritage. In Studies in Forensic Biohistory: Anthropological Perspectives, edited by Christopher M. Stojanowski and William N. Duncan. Cambridge University Press, Cambridge, pp. 43-66. DOI: 10.1017/9781139683531.003.

Tourigny, Eric, Richard Thomas, Eric Guiry, Richard Earp, Andrew Allen, Jamie Rothenburger, Dennis Lawler, and Marc
Nussbaumer. 2016. An osteobiography of a 19th-century dog from Toronto, Canada. International Journal of Osteoarchaeology 26(5):818-829. DOI: 10.1002/oa.2483.

Väre, Tiina. 2017. Osteobiography of Vicar Rungius: Analyses of the Bones and Tissues of the Mummy of an Early 17th Century Northern Finnish Clergyman using Radiology and Stable Isotopes. Ph.D. dissertation, University of Oulu. Acta Universitatis Ouluensis, Oulu.

Vlok, Melandri, Victor Paz, Rebecca Crozier, and Marc Oxenham. 2017. A new application of the bioarchaeology of care approach: A case study from the Metal Period, the Philippines. International Journal of Osteoarchaeology 27(4):662-671. DOI: 10.1002/oa.2588.

Williamson, Ronald F., and Susan Pfeiffer. 2003. Bones of the Ancestors: The Archaeology and Osteobiography of the Moatfield Ossuary. Canadian Museum of Civilization, Gatineau. DOI: 10 .2307/j.ctv16q3w. 